\title{
MANAGING COMPETENCE AND CERTIFYING PERSONS RESPONSIBLE FOR FUNCTIONAL SAFETY
}

\section{ZARZĄDZANIE KOMPETENCJAMI \\ I CERTYFIKACJA OSÓB ODPOWIEDZIALNYCH ZA BEZPIECZEŃSTWO FUNKCJONALNE}

Kazimierz T. Kosmowski ${ }^{1}$, Marcin Śliwiński ${ }^{2}$

Gdansk University of Technology, Narutowicza 11/12, 80-233 Gdansk, Poland E-mail: (1)k.kosmowski@ely.pg.gda.pl (2)m.sliwinski@ely.pg.gda.pl

Abstract: This article emphasizes that knowledge and competences of managers, engineers and specialists dealing with safety-related technologies for hazardous industry should be appropriately shaped in the technical education processes and training programmes fulfilling some quality requirements and assessment criteria. It concerns especially persons dealing with the functional safety solutions in the design and operation of the electric, electronic and programmable electronic (E/E/PE) systems. Such persons can now be certified in Poland according to a certification system developed by a Programme Committee consisting of experts from the industry and two Technical Universities (in Gdansk and Warsaw). This committee was created within the Office of Technical Inspection (UDT-CERT) in Warsaw. The UDT-CETRT is formally responsible for certifying persons dealing with functional safety solutions.

Keywords: Functional safety, managing competence, certifying persons

Streszczenie: Niniejszy artykut podkreśla, że wiedza i kompetencje menadżerów, inżynierów $i$ specjalistów zajmujących się technologiami zwiąanymi $z$ bezpieczeństwem dla przemystu podwyższonego ryzyka powinny być odpowiednio ksztattowane $w$ procesie edukacji technicznej $i$ programach szkoleniowych spetniajacych pewne wymagania jakościowe i kryteria oceny. Dotyczy to zwłaszcza osób zajmujących się rozwiązaniami bezpieczeństwa funkcjonalnego $w$ projektowaniu $i$ eksploatacji systemów elektrycznych / elektronicznych / programowalnych elektronicznych (E/E/PE). Osoby takie moga być obecnie certyfikowane $w$ Polsce, zgodnie $z$ systemem certyfikacji opracowanym przez Komitet Programowy składajacy się z ekspertów z przemystu i dwóch Politechnik (w Gdańsku $i$ Warszawie). Komitet ten zostat utworzony w Urzędzie Dozoru Technicznego (UDT-CERT) $w$ Warszawie. UDT-CERT jest formalnie odpowiedzialny za certyfikację osób zajmujących się rozwiazaniami bezpieczeństwa funkcjonalnego.

Stowa kluczowe: Bezpieczeństwo funkcjonalne, zarzadzanie kompetencjami, certyfikacja osób 


\section{Introduction}

The European Union has defined a number of objectives for advanced Research and Technological Development (RTD) activities that require a variety of concerted actions (Improving..., 2007). There are new challenges concerning research, education and training in area of safety and security of hazardous plants and critical networks/systems. This article emphasizes that knowledge and competences of managers, engineers and specialists dealing with safety-related technology for hazardous industry should be appropriately shaped during technical education processes and relevant training programmes fulfilling some quality requirements and assessment criteria.

Therefore, it is necessary to develop new education curricula and training standards sharing the results of research and best experience from the industry for effective managing competences. Similar view is proposed in a strategic programme of the European Technology Platform on Industrial Safety (ETPIS) (Safety.., 2006) and Polish Technological Platform on Safety at Work in Industry (PPT BPP) (Strategic.., 2009). The article addresses especially the issue of specialists' competence dealing with functional safety during the design and operation of electric, electronic and programmable electronic (E/E/PE) safety-related systems (IEC 61508, 1998).

The required scope of knowledge for CSBF (Certyfikowany Specjalista Bezpieczeństwa Funkcjonalnego) - Certified Functional Safety Professional and CEBF (Certyfikowany Ekspert Bezpieczeństwa Funkcjonalnego) Certified Functional Safety Expert in the certification system of persons responsible for functional safety has been developed in Poland by the Programme Committee created within the Office of Technical Inspection (UDT-CERT) (Certification.., 2009). This committee consists of specialists and experts form the industry and two Technical Universities (in Gdansk and Warsaw). This programme is similar in some respects to international certification system CFSP/CFSE (Certified.., 2010), but it differs significantly in some details from the second one. Examples of training programmes compatible with the examination topics within the certification system in Poland are presented and discussed.

The functional safety methodology is described in relevant standards (IEC 61508, 1998; IEC 61511, 2002; EN 62061, 2005; IEC 61513, 2001) and guidelines (Guidelines.., 1993, Layer.., 2001). There are, however, still some challenges to improve this methodology (Kosmowski 2006) for successful implementation of advanced functional safety solutions in 
industrial practice (Kosmowski \& Rogala, 2007, Kosmowski \& Śliwiński, 2009). It requires also implementing relevant safety-related education and training programmes for shaping knowledge and improving competences (Dźwiarek, et al., 2004, Managing.., 2006).

\section{Research and training challenges}

\subsection{Strategic research programme in area of industrial safety}

The Strategic Research Agenda (SRA) (Safety.., 2006) developed by the European Technology Platform on Industrial Safety (ETPIS) is a tool for co-ordinating the Research and Technical Development (RTD) efforts to be undertaken in area of industrial safety at European, national and regional levels to prepare and implement advanced research programmes. One of the objectives is to develop synergies between public and private sectors at relevant levels to optimise the resources allocated to research in area of industrial safety.

The SRA constitutes the RTD roadmap for industrial safety improvement. It was assumed that the national technology platforms on industrial safety will provide contribution in resources and research works, and this would be coordinated by the ETPIS. In Poland the Strategic Research Programme prepared by the Polish Technology Platform on Safety at Work in Industry (PPT BPP) was developed and several research activities were initiated including those related to preventing of major accidents (Strategic.., 2009).

The organisation of the RTD strategy has been structured based on the analysis of the broader situation, regarding industry and safety-related interactions. It led the ETPIS members to propose RTD strategy that focuses on several major challenges. Present organisational structure consists of 5 Focus Groups (FGs) and 2 HUBs plus 1 newly proposed HUB (Security) (Safety.., 2006):

- Risk Assessment and Management;

- Advanced Risk Reduction Technologies;

- Structural Safety;

- Human and Organisational Factors;

- Emerging Risks;

- HUB Education and Training;

- HUB NanoSafety;

- HUB Security.

To enable the mobilisation of the critical mass to solve interdisciplinary problems and attract the interested sectors, the ETPIS has decided to 
propose a conception of research HUBs. A research HUB is a topic-based group of stakeholders aiming at exchanging knowledge and starting projects, once they have defined a research agenda that is relevant to their topic of interest. As it was specified three research HUBs have been created:

- Education and training - it aims at developing new technologies and methods to improve the knowledge transfer to industry, and to the engineers and scientist working in the field of safety;

- NanoSafety - it addresses safety-related issues in the field of nanotechnologies and nano-materials;

- Security - it addresses the security-related issues that are very important in some industrial plants, systems and networks (hazardous plants, ICT, electric grid, gas and oil pipelines, etc).

Various topics associated with accident and crisis situation management have been included in the SRA. Many of them are oriented on understanding the impact of human and organisational factors (H\&OFs) in the risk control. Basic knowledge, methods and technologies planned to be developed include (Safety.., 2006):

- Human and Organisational Factors in Safety Management;

- Human-Centred Design;

- Integrated Risk Assessment and Management Methods \& Techniques;

- Human Performance \& Technology Usability;

- Human Factors in Emergencies and Crisis Management.

\subsection{Strategic research programme of PPT BPP}

Although the organisation of the Polish Technology Platform on Safety at Work in Industry (PPT BPP) (Strategic.., 2009) is different than ETPIS, it includes a number of similar topics in the strategic research programme.

The activity conception of PPT BPP assumes cooperation between companies, scientific institutions, government and groups of receivers and social organizations. An important objective of its activity is to build a bridge between science and industry through initiating and carrying out the research and contribute in the future to commercialisation of scientific solutions and new technologies.

The PPT BPP consists of following working groups:

- Technologies for reducing occupational risk;

- Methods for risk assessment and management;

- Human and organisational factors in work processes; 
- Education and development of safety culture;

- Prevention of serious accidents in industry.

The strategic research programme in its part concerning prevention of major accidents in industry includes detailed description of methods and tools to be developed by the end of 2010 and in a next step by the end of 2013 . Some of them are as follows:

- Tools for risk analysis and assessment of serious accidents;

- Methods and tools for preventing of serious accidents and reduction of their risk;

- Safety management in industrial companies and on areas of potential consequences due to serious accidents;

- Procedures and tools for responding to accidents and management of crisis situations.

\subsection{Research challenges concerning integrated safety management}

The main target is the development of integrated methodologies for risk management addressing complexity (including multi-hazard and naturaltechnological hazard situations), multifunctional use of space and increasing population densities with the aim of reducing overall risk and detrimental impact to society.

It is expected that approaches to be developed should be based on societal cost-benefits to reduce impact on human health and environment. Integrating new safety concepts related to technical, human, organisational and cultural aspects and building on-line risk assessment tools that will continuously monitor the interactions in the industrial systems during their life cycle should lead to a new safety paradigm and radical health and safety improvement.

Research efforts should underpin EU policies on industrial safety, mainly the Health and Safety at Work directive (89/391/EEC 12/6/1989) and the HSW action plan (COM(2002) 118 final), the Major Accidents Seveso II directive (96/82/EEC 9/12/1996), the Explosive Atmospheres ATEX directive (99/92/EC), and the Integrated Pollution Prevention and Control IPPC directive (96/61/EC 24/9/1996). It is expected that the adoption of this new safety paradigm will improve industry competitiveness as well as will favour transforming Europe towards a more risk informed and innovation accepting society. 


\section{Competences through education, training and experience}

\subsection{Planned activities of ETPIS in area of education and training}

The specific focus of the Education and Training HUB (Safety.., 2006) will be oriented on activities for coherent education and training of managers, workers and public on all issues, principles and methods relevant to industrial risk analysis, risk prevention, risk mitigation, risk management as well as on occupational health and safety, along their life, from school to universities, work time, and social activities. Education and training has a major role in:

- Shaping the safety knowledge and safety culture;

- Creating and enhancing skills for identifying, assessing and managing risks;

- Maintaining and enhancing personal awareness and professional competencies in safety-related problems;

- Collaborating to improve safety;

- Disseminating and implementing research results.

The ETPIS proposals use the conclusions and recommendations of the report of the OECD Workshop on sharing experience in the training of engineers in risk management (March 2004). According to this report the education and training programmes for students and engineers should provide them with adequate knowledge in risk assessment and risk management, because their actions may have an impact on human health, the environment, or the property. It is suggested that "...training is moving to a more integrated approach, involving concepts from a number of disciplines (including social sciences and humanities) to expand the perspectives of engineers and to promote a multidisciplinary approach to decision-making". Similar approach was lately proposed in Poland (Strategic.., 2009).

\subsection{Some remarks on a guide for managing competence}

The guidance (Managing.., 2006) was issued by the Health and Safety Executive (HSE), the Institution of Electrical Engineers (IEE) and the British Computer Society (BCS). This guidance is not compulsory and responsible staff is free to take other action. But if he/she does follow the guidance one will normally be doing enough to comply with the law to be regulated by the Health and Safety Executive. HSE inspectors seek to secure 
compliance with the law and may refer to this guidance as illustrating good practice.

This guidance is applicable to the development and use of safety-related systems in all industry sectors. A safety-related system (as limited by the scope of this document) is a system whose correct operation is necessary for ensuring or maintaining safety. It uses electrical, electronic, and/or programmable electronic technologies and may include software and people. In general, safety-related systems can be classified as protective systems or continuous control systems.

The guidance is based on a number of high-level principles, with associated specific guidance on the practical realisation of those principles, encompassing information, explanation and examples. It is applicable to everyone whose decisions and work with safety-related systems can affect health and safety.

According this guidance the personnel to be concerned with managing competence include:

- those responsible for safety in an organisation,

- those responsible for setting up a new competence management system or evolving an existing competence management system (CMS),

- those responsible for operating an established CMS,

- those responsible for career development of staff in an organisation,

- staff in an organisation that are employed, or might be employed, on projects that require formal management of competence.

The guidance (Managing.., 2006) is aimed primarily at the first two groups of people - those who are responsible for managing and assuring the competence of individuals and teams that might have an impact on the functional safety of safety-related systems, during any phase of design, development, manufacturing, operation, maintenance or modification.

The activities that an organisation performs can be viewed in a variety of ways - as a hierarchy, or as a network of interconnected processes. But generally members of staff work either individually or in teams to fulfill some well-understood function - such as 'Procurement', 'Software design', or 'Instrumentation testing'. Some functions might be quite static performed by single departments in the organisation. Other, for example in a projectbased organisation might have several instances as distinct teams 'Software integration', for instance - within the various project teams. 
Functions comprise tasks. In the competence model a task is the smallest unit of activity. A competence standard for a task might express an expectation of some technical skill appropriate to the task, but there will also, in general, be competence standards that encapsulate expectations of behavioural skills, such as team working, and required knowledge of the risks in a particular application domain, for instance.

In the Safety, Competence \& Commitment model this is addressed by introducing the concept of 'levels' of competence. For each of the competence standards, both those that are task-related and those that are function-related, three levels of competence are recognised: 'Supervised practitioner', 'Practitioner', and 'Expert'. A person who does not yet possess sufficient competence to be considered a 'Supervised practitioner' is termed a 'Trainee' with regard to that particular competence standard. Individuals will have a competence profile with differing levels of expertise with respect to different competence standards. Each individual contributes to a function by performing a role. Each role requires at least a minimum profile of competence (Managing.., 2006).

\subsection{Competences in the domain of functional safety}

IEC 61508 indicates the need of “...ensuring that applicable parties involved in any of the overall E/E/PE or software safety lifecycle activities are competent to carry out activities for which they are accountable" ( Part 1, Paragraph 6.2.1h). There are few common fields on which personnel competence should meet IEC requirements:

- general knowledge about designing and operating of functional safety solutions using E/E/PES (IEC 61508, 1998) or SIS (IEC 61511, 2002) in overall protection systems;

- expert knowledge concerning the details of the functional safety technology based on the hazards analysis, risk assessment to determine required safety integrity level (SIL) of safety-related functions and verifying SIL based on probabilistic modeling of the E/E/PE (or SIS) architectures considered.

It should be emphasized the functional safety is to be managed in life cycle to decrease the probability of random failures to a specified level, but also to avoid the systematic failures, e.g. software errors and other errors including those related to human and organizational factors (Kosmowski, 2006). 


\section{Certifying persons responsible for functional safety}

\subsection{An international certification system}

One of more known concepts for certifying the industry engineers was initially developed by some international institutions including TÜV and EXIDA (Certified.., 2010). Its aim was to certify the personnel competence dealing with functional safety in lifecycle to meet requirements and criteria given in international standards IEC 61508, IEC 61511 and EN 62061. Two levels of competence are proposed to be certified in this system:

- Certified Functional Safety Professional (CFSP);

- Certified Functional Safety Expert (CFSE).

Certificate of competency can be listed in one of four main fields connected with specific industry application:

- Process Industry Safety;

- Machinery safety;

- Safety Software Development, and

- Safety Hardware Development.

To pass the CFSE certification process an applicant is not forced to participate in any specific course. The certification process involves a review of the applicant's background and satisfactory completion of a proficiency exam. The background review includes proof of completion of an applicable engineering curriculum and review of relevant professional experience. However, it is worth to join a training course to review own knowledge. Typical program of training is fulfilled in one or two day's long courses with entire program to meet exams curriculum (Certified.., 2010).

\subsection{A certification system proposed in Poland}

The certification programme (table 1) is designed for persons responsible for functional safety distinguishing (Certification.., 2009; Kosmowski \& Śliwiński, 2009). Its basic features are as follows:

- two levels of qualification: I - general and II - expert;

- four specializations: A - hardware and software, B - process industry, $\mathrm{C}$ - machinery, and $\mathrm{D}$ - nuclear power plants.

The proposed UDT-CERT system (Certification.., 2009) is relevant to international certification (IC) as follows:

- I (CSBF) - IC CFSP,

- IIA (CEBF-A) - IC CFSE-Safety Hardware Development, 
- IIA (CEBF-A)- IC CFSE-Safety Software Development,

- IIB (CEBF-B) - IC CFSE -Process Safety Applications,

- IIC (CEBF-C) - IC CFSE-Machinery Applications.

Table 1. The certification programme for persons responsible for functional safety

\begin{tabular}{|c|l|c|}
\hline Level & Specialty & Standards \\
\hline I - General: & & $\begin{array}{c}\text { PN-EN 61508 - general } \\
\text { and cross-sectional: }\end{array}$ \\
\cline { 3 - 3 } $\begin{array}{c}\text { Certified Specialist } \\
\text { of Functional } \\
\text { Safety (CSBF) }\end{array}$ & & PN-EN 61511 \\
\cline { 3 - 3 } & & PN-EN 62061 \\
\cline { 2 - 3 } $\begin{array}{c}\text { II - Expert: } \\
\text { Certified Expert of } \\
\text { Functional Safety } \\
\text { (CEBF) }\end{array}$ & $\mathrm{A}$ - hardware and software & IEC 61513 \\
\cline { 2 - 3 } & $\mathrm{B}$ - process industry & PN-EN 61508 \\
\cline { 2 - 3 } & $\mathrm{C}$ - machinery & PN-EN 6206151 \\
\cline { 2 - 3 } & & IEC 61513 \\
\hline
\end{tabular}

The difference of these two systems is that in case of international certification the general level CFSP is related directly to the expert level domain (it is written CFSP/CFSE), whereas in the UDT-CERT system it was assumed that Certified Specialist of Functional Safety (level I) should acquire general and cross-sectional knowledge.

The scheme of training courses and their minimal time requirements are shown in Figure 1. The training courses Ia (Diagnostics of Processes and Systems) are organized: by the Warsaw University of Technology (WUT) at the Laboratory of Professor J. M. Kościelny and the training courses $\mathrm{Ib}$ (Functional Safety) by the Gdansk University of Technology (GUT) at the Laboratory of Professor K.T. Kosmowski. These laboratories have a status of the Training Centres given after an audit by UDT-CERT.

The programme of the training course Ib includes following topics:

- General requirements included in PN-EN 61508 standard and its relations with sector standards PN-EN 61511 and PN-EN 62061;

- Important terms and definitions concerning reliability and safety of elements and systems; individual risk and societal risk;

- Concepts and objectives of functional safety management in life cycle;

- Competence requirements and those concerning the documentation, updates and supervision of analyses/assessments;

- Hazards identifying and documenting safety-related functions; 
- HAZOP in analyses of potential events and accident scenarios;

- Determining required safety integrity level (SIL) based on risk analysis and assessment; the risk matrix method;

- ALARP for assessment of risk control options;

- Potential systematic errors in E/E/PE systems and their avoiding; meaning of software quality and relevant requirement in life cycle;

- Requirements concerning software specification and safety; communication protocols and network security;

- Failure modes of components, reliability data and their updating in time;

- Probabilistic criteria for distinguished modes of the E/E/PE subsystems' operation;

- Architecture constraints concerning the E/E/PE subsystems;

- Examples of E/E/PES solutions for implementing the safety-related functions;

- Verifying SIL using qualitative methods; features of quantitative methods;

- Problem of dependent failures and rules for decreasing the influence of CCF;

- Layer of Protection Analysis (LOPA) according to PN-EN 61511; using the event tree method defining accident scenarious;

- Human factors in analyses of functional safety and protection layers; functional analysis and assessment of interfaces and the alarm system solutions;

- Functional safety of machinery control systems according to PN-EN 62061;

- Conditions for diagnosis of components; planning of maintenance and tests of $\mathrm{E} / \mathrm{E} / \mathrm{PE}$ subsystems;

- Meaning of the RCM, RBM and RBI methods in safety management;

- Cost-benefit analysis (CBA) for assessment of technical and organizational solutions of functional safety.

At the end of the courses the participants are passing the tests of knowledge. If they pass relevant tests a certificate Ia from Warsaw University of Technology and Ib from Gdansk University of Technology is issued, which are required to take a final exam for CSBF at UDT-CERT in Warsaw. If the final exam is successful the participant fulfills some additional requirements he becomes Certified Specialist of Functional Safety (CSBF). The training courses and exams for CEBF-A and CEBF-A are planned by the end of 2010 . 


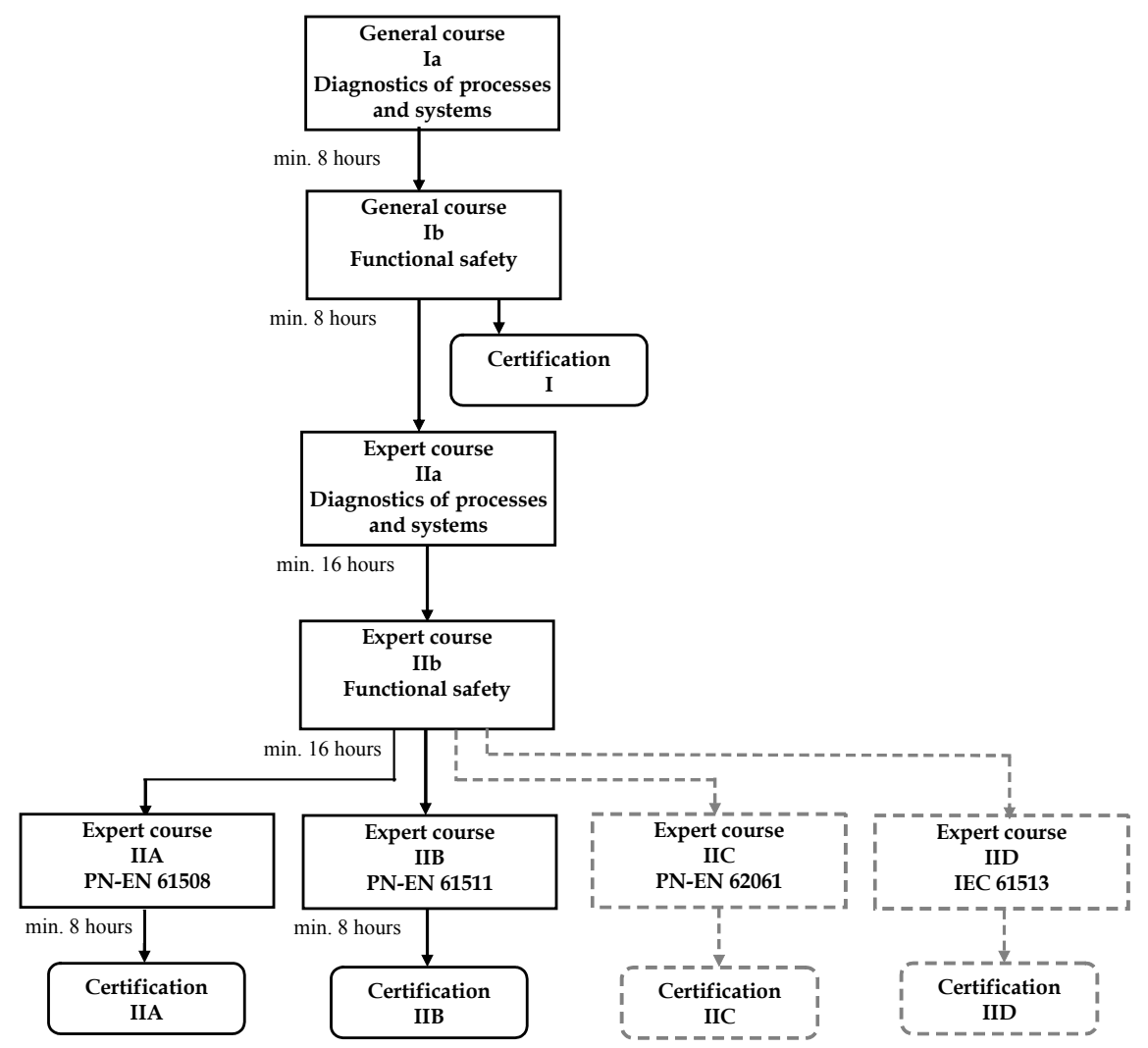

Fig. 1 Scheme of training courses and their minimal time requirements

The Certification Programme for Persons Responsible for Functional Safety was developed with regard to the international standard concerning Conformity assessment - General requirements for bodies operating certification of persons (ISO/IEC 17024, 2004). The details of this certification programme including courses IIa, IIb, IIA and IIB are described in the documentation available at UDT-CERT (Certification.., 2009). The courses IIC and IID will be organized from 2011.

There are following requirements concerning experience of specialist/ experts related described above certification programme:

- 3 years of equivalent engineering experience to become CSBF, and

- 10 years equivalent engineering experience to become CEBF.

There are some credit years to be subtracted form these numbers of years depending on engineering education background of candidates (Certification.., 2009). 


\section{Concluding remarks}

There are new challenges concerning research, education and training in the domain of safety and security of critical systems and networks. In this article some topics that are included in a strategic programme of the European Technology Platform on Industrial Safety and some other proposals how to deal with current safety-related problems are described. The issue of competences of specialists dealing with functional safety in the design and operation of electric, electronic and programmable electronic (E/E/PE) safety-related systems is emphasized. The certification Programme for Certified Specialist of Functional Safety (CSBF) and Certified Functional Safety Expert (CEBF) is outlined.

The managing competence is especially important in area of functional safety. The relevant issues concerning the functional safety and competence management were included in the current programme of the Polish Technological Platform on Safety at Work in Industry (PPT BPP). The related research and implementing works that are related to managing competence should be intensified.

Acknowledgements: The authors wish to thank the Ministry for Science and Higher Education in Warsaw for supporting the research and the Central Laboratory for Labour Protection - National Research Institute (CIOP-PIB) for co-operation during preparation and realization of the research project concerning the safety management of hazardous systems including the human reliability and functional safety aspects.

\section{References}

1. Certification Programme of Persons Responsible for Functional Safety. The Office of Technical Inspection (UDT-CERT), Warsaw, December 2009.

2. Certified Functional Safety Expert, CFSE Governance Board, http://www.cfse.org/, Access: March 2010.

3. Dźwiarek M., Kosmowski K.T., Missala T.: Integrated training programme in the process of implementation of advanced functional safety solutions in Poland (in Polish). In: Functional Safety Management. Gdańsk: Fundacja Rozwoju Uniwersytetu Gdańskiego, 2004. ISBN 83-89786-05-2.

4. Guidelines for Safe Automation of Chemical Processes. Center for Chemical Process Safety of the American Institute of Chemical Engineers. New York, 1993.

5. Improving quality and productivity at work: Community strategy 2007-2012 on health and safety at work. Communication from the Commission of the European Parliament, the Council, the European Economic and Social Committee and the Committee of the Regions. Commission of the European Communities. $\operatorname{COM}(2007) 62$ final. Brussels, 21.2.2007. 
6. Kosmowski K.T.: Functional safety concept for hazardous systems and new challenges. Journal of Loss Prevention in the Process Industries 19, 2006 (298-305).

7. Kosmowski K.T., Rogala I.: Functional safety and managing competence In: Functional Safety Management in Critical Systems. Gdańsk: Fundacja Rozwoju Uniwersytetu Gdańskiego, 2007. ISBN 978-83-7531-006-1.

8. Kosmowski K.T., Śliwiński M.: A concept of training courses for certification of persons in area of functional safety. Gdansk University of Technology, April 2009.

9. Layer of Protection Analysis - Simplified Process Risk Assessment. Center for Chemical Process Safety of the American Institute of Chemical Engineers. New York, 2001.

10. Managing Competence for Safety-related Systems. The guidance to be issued by the Health and Safety Executive, the Institution of Electrical Engineers and the British Computer Society, 2006.

11. Safety for Sustainable European Industry Growth, Strategic Research Agenda of the European Technology Platform on Industrial Safety (ETPIS), Jan. 2006.

12. Strategic Research Programme (in Polish). Polish Technology Platform on Safety at Work in Industry (PPT BPP), Central Research Institute of Labor Protection - State Research Institute (CIOP-PIB). Warsaw, January 2006. Group 5: Preventing from major accidents; updating December 2009.

13. EN 62061: Safety of machinery - Functional safety of safety-related electrical, electronic and programmable electronic control systems, 2005.

14. IEC 61508: Functional safety of electrical/ electronic/ programmable electronic (E/E/PE) safety related systems. Parts 1-7. International Electrotechnical Commission, 1998.

15. IEC 61511: Functional safety: Safety Instrumented Systems for the process industry sector. Parts 1-3. International Electrotechnical Commission, 2002

16. IEC 61513: Nuclear power plants - Instrumentation and control for systems important to safety - General requirements for systems, 2001.

17. ISO/IEC 17024: Conformity assessment - General requirements for bodies operating certification of persons, 2004.

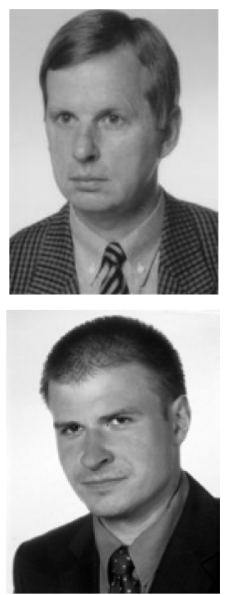

Kazimierz Kosmowski Prof., received Ph.D. in 1981 and D.Sc. in 2003 from Gdansk University of Technology (GUT). Since 2006 the manager of Division of Control Eng. at Faculty of Electrical and Control Eng. and since 2007 a vice-chairman of Polish Safety and Reliability Association (PSRA). Specialization: reliability and safety of technical systems, human reliability, functional safety of the programmable control and protection systems.

Marcin Śliwiński PhD. received PhD. in 2006 from Gdansk University of Technology (GUT). From 2001 researcher and since 2006 lecturer at Faculty of Electrical and Control Engineering. Specialization: information technologies, distributed computer networks, expert systems, functional safety of the programmable control and protection systems, probabilistic modelling of technical systems. 